\title{
Refinement as a Strategy for the Development of Private Schools
}

\author{
Huang Jian \\ Xijing University, Xi’an, China, 710123
}

Keywords: private schools; development; strategy; refinement

\begin{abstract}
The refinement of education is an important trend of contemporary educational reform. To achieve steady and rapid development of private schools, it is necessary to carefully design all aspects of education and teaching, carefully operate and keep improving. This paper gives some superficial views on the enrollment behavior of private schools in the basic education stage, the special status in the education structure and how to be refined.
\end{abstract}

\section{Introduction}

Refinement is the important trend of contemporary education reform, and a new concept and strategy of educational reform and development. It is a management realm that emphasizes process and detail, strives for excellence and keeps improving. Under the current background, private schools not only have great opportunities for development and development, but also have contradictions and risks in the development process. I think the refinement of education is a fundamental strategy for the steady and sustainable development of private schools.

\section{The Refinement of Education Determined by the Marketization of Enrollment Behavior of Private Schools}

At present nine years of compulsory education in all parts of the province, the enrollment of school enrolment has been exempted. Under the enrolment model of planned economy, some public schools are protected by policies, such as some key schools, which have been given special care and protection in both financial policies and sources, and become a disguised monopoly. In private schools, there is no national designated enrollment plan, and whether students come or not is entirely market behavior. In the previous years, in the initial period of the establishment of private schools, some private schools adopted a cross province and cross regional enrollment strategy, that is, to recruit students in provinces and regions which are relatively backward in the development of educational undertakings, so that schools can be developed into a certain scale. It should be seen that this situation can only occur at the beginning of the development of private schools. With the continuous adjustment of the development of private education policy in China, from the original "supplement" to the present "common development", the private schools in all provinces and cities will be more and more. As a result, there will be fewer and fewer students from other provinces and cities. Localization of private school students will become the mainstream. In this case, every private school will compete with the local key schools for the source of life, not to be more refined than others, students will not come to your school to read. On the other hand, private schools, because there are no national financial allocations, maintain a lot of expenses for the operation of schools, so the fees are much higher than those of public schools. The reason why parents have high prices to educate their children is because they hope to have a high return, that is, to make children better educated than public schools and to make their children better. If this wish can't be realized, the parents will abandon you. Without students, or without a certain number of students, the school will be closed. In this sense, only by delicacy, private schools will have market to survive and develop.

The refinement of education is determined by the special status of private schools in the regional education structure.

It can be said that, in addition to Zhejiang, the proportion of private schools in most provinces 
and regions of the country is negligible in the educational structure of the region, especially in Lianyungang, which is backward in economic and cultural education, especially in our city. In recent years, the municipal government has identified the "science and education to promote the market" as one of the five major development strategies of the economy and society. The government at all levels invested a lot in education. All walks of life and the people of the society carry forward the glorious tradition of "tighten the belt run education", and vigorously support the development of education. Nowadays, all the counties and districts in the city have a number of ordinary schools that can afford quality and facilities.

\section{Refinement of Education as the General Trend of the Survival and Development of Private Schools}

Looking at the birth and development of private schools at this stage, it embodies the idea of educational refinement. At the beginning, the Changzhou international school, the Wuxi Guanghua School and the Chinese British schools in Conghua, Guangdong were called "aristocratic schools" because of their school architectural design, the overall concept of education and teaching and the implementation of their life, which was the first class at the time. It's precisely because of its "exquisite" that it provides people with high quality and satisfactory education for the masses. That can produce such a big bang effect. It may be said that many private schools in the South were red at the time, but now they have failed. How should I explain them? In my opinion, there are many reasons for the failure of these schools, but the most important thing is that at the beginning of this century, the education modernization project was carried out in the public schools in the south, the quality of education and teaching was improved rapidly, and the private schools still stayed at the original level of running the school, that is, it did not really achieve the refinement of education. Let's take a look at the developed countries and regions in the world. Private schools are usually high fees and high quality.

The primary problem of a private school is to solve the problem of self development. If it is to make money, that is the opening shop, not the school. If it is to run a decent private school, the reference coefficient will be too low to become a permanent one. We believe that running schools is like doing anything. The reference points must be high. We must dare to compete with schools and even key schools. This goal orientation is very important for private schools, which determines the lifeblood of schools. The goal of school development is high. We must constantly improve the conditions of running schools, expand the scale of running schools and improve the efficiency of running schools. I will not adopt "people do not want me" or "I do not accept" on the issue of enrollment, but choose cautiously, pay attention to the starting point and stress plasticity. The idea of running a school to be advanced is to truly meet the requirements of quality education, keep pace with the times, promote the idea of "providing the best and feasible education for the students and making every student succeed", and to make this idea truly a concrete action of the faculty and staff, and indeed provide a good teaching from all aspects to the students. Education ensures that every student is fully and equitable.

\section{The Curriculum should be Avant-garde, and the Facilities Should be Advanced}

Curriculum is the carrier to achieve the goal of teaching. According to the requirements of quality education, private schools should carefully design non examination school-based courses on the basis of guaranteeing the establishment of national courses and local courses, which can not be opened in public schools because of the limitations of funds and teachers' conditions. People often say that the curriculum structure will determine the quality structure of students. This is reasonable. We should also note that the characteristics of the so-called school education, first of all, are embodied in the curriculum. The private schools should make full use of their own advantages. In accordance with the requirements of quality education, the school based curriculum system should be carefully designed, leading to the competitiveness of other schools. At the same time, there should be advanced educational facilities matching courses. The educational facilities of private 
schools are usually better than those of ordinary civic schools at the start-up stage. In the first place, the private schools were called "noble schools" because the facilities were better than the public schools. However, with the advancement of education modernization project, the advantages of private schools in terms of educational facilities will gradually be lost. If the private schools do not constantly renew their ideas on the construction of educational facilities, they can not make the facilities and equipment of the schools ahead of the public schools, and the private schools will lose their corresponding competitiveness, and the parents will not spend a lot of money to send their children to a poor school. Therefore, the educational equipment of private schools should be built according to the principle of leading ahead, which is obviously advanced in general public schools and even key schools in the local areas.

\section{The Quality of Teachers Should be High and the Quality of Education Should be First-class}

High quality teaching staff is a basic condition for high quality education. High quality education is the lifeline of private schools. Therefore, private schools must create a highly qualified faculty. To give students a bowl of water, the teacher must be long running water. A master is an apprentice. Teachers are not only the transmitters of knowledge, but also the guide of morality, the enlightened of thought, the pioneer of the mind world, the creator of emotion, will and faith; the teacher needs not only to know what to impart knowledge, but also to know how to impart knowledge, and to take different teaching strategies for different students. Therefore, if a private school wants to survive and develop and become a famous school, it must focus on building a high-quality contingent of teachers. The quality of education is not only refers to the change of civilized manners and behavior habits after the students come to school, but also the school based curriculum for the students to develop the quality of the students in an all-round way, and more importantly, the teaching achievement of the examination subject in the national curriculum is also better. Therefore, I believe that the quality of education we are talking about at this stage is still the quality of education centered on the Chinese university entrance examination. First of all, don't avoid the baton of the college entrance examination. Secondly, do not deny that the college entrance examination is still an important indicator of the quality of education. It can not be considered that the high level of college entrance examination represents the low level of quality education. The high rate of entrance examination is still an important reflection of the high level of quality education. It can not be said that your college entrance examination rate is low. In turn, your quality education is good. There is no such strange thing and you should not have such a confused understanding. A considerable number of private schools have brought students in, and they are not allowed to take part in the regional unified examination, or have been dealt with, so that some of the students with good results will take part in the regional examination, and a considerable number of students only take part in the low standard and non-standard examination organized by the school. Education and teaching information is self-closed. In the long run, the problem is accumulating, resulting in distrust of students' parents' teaching quality. Therefore, in order to survive and develop, private schools must take the initiative to accept the guidance and evaluation of local education departments, realize the socialization of educational evaluation, integrate into the mainstream of local education evaluation, and strive to reach the top.

\section{Conclusion}

Of course, it is a complicated and arduous process that the orientation of running a school, the determination of the idea of running a running school, the setting of the curriculum, the equipment, the construction of the teacher team and the overall improvement of the quality of education and teaching. In this process, there are many links, many steps, and each participant needs careful planning and careful operation to achieve the desired result. 


\section{References}

[1] Cai Keyong: where did Chinese education go in twenty-first Century? Jilin people's Publishing House 2007 edition.

[2] Zhong Qiquan and Zhang Hua edited: outline of the basic education curriculum reform (try out), East China Normal University press, 2006 edition.

[3] editor: "Hail to the Jianfu Department of education teacher education reform and update our concepts of Education published". 